Thorax, 1978, 33, 235-242

\title{
Pus, deoxyribonucleic acid, and sputum viscosity
}

\author{
R. PICOT, I. DAS, AND L. REID ${ }^{1}$ \\ From the Department of Experimental Pathology, Cardiothoracic Institute, Brompton Hospital, \\ Fulham Road, London SW3 6HP
}

Picot, R., Das, I., and Reid, Lynne (1978). Thorax, 33, 235-242. Pus, deoxyribonucleic acid, and sputum viscosity. On 100 sputum specimens selected from patients suffering from chronic bronchitis, bronchiectasis, asthma, and cystic fibrosis total deoxyribonucleic acid (DNA) content has been related to macroscopic type, to total dry weight yield, and to the apparent viscosity of the secretion at $1350 \mathrm{~s}^{-1}$ : since DNA may be present, either as fibres or within cells, in one-third of the specimens the contribution of each form to the apparent viscosity was assessed. The effect on sputum viscosity of the addition of DNA in vitro has also been studied.

Whereas between mucoid, mucopurulent, and purulent macroscopic types a significant difference in total DNA and dry weight yield has been found, viscosity was not significantly correlated with purulence. Similarly, the concentration of either cells or fibres correlated significantly with total DNA but not with viscosity. The in vitro addition of DNA to sputum caused a significant increase in its viscosity, and reasons for the differences between the in vivo and in vitro effect are discussed. Certain constituents of purulent sputum tend to increase viscosity and others to reduce it, and the influence of these varies in the several diseases studied.

In the third century BC, Hippocrates used the heat or flotation test as well as colour, taste, and smell of sputum as diagnostic and prognostic criteria in the treatment of patients, and in modern times, good agreement has been found between macroscopic type and cell counts, providing a scientific basis for the earlier subjective assessment. Although macroscopic examination can give a rough idea of the amount of pus present in sputum, a more quantitative assessment of pus calls for more precise methods, such as estimation of total DNA or of lactate dehydrogenase (LDH) activity.

The importance of pus on the rheological properties of sputum has received much attention over the last 15 years, but there is still controversy as to whether purulent sputum is more viscous. In 1962 Bruce and Quinton, studying patients with chronic bronchitis, reported that mucoid sputum was more viscid than purulent; but the sputum they studied was already degraded since they sheared it to consistency before measuring viscosity. 1Present address: Department of Pathology, Children's Hospital
Medical Center, Harvard Medical School, Boston, Mass., USA.
Testing sputum soon after it was produced and at the low shear rates possible with the Weissenberg rheogoniometer, Sturgess et al. (1971) found no significant difference between viscosity of purulent sputum from patients with bronchiectasis and mucoid samples from patients with chronic bronchitis. Using the Ferranti-Shirley viscometer and comparing apparent viscosity at the higher shear rates of $1350 \mathrm{~s}^{-1}$, Charman and Reid (1972) studied mucoid, mucopurulent, and purulent samples from four diseases-chronic bronchitis, cystic fibrosis, bronchiectasis, and asthma, and again the differences were not significant.

By contrast, Feather and Russell (1970) and Palmer et al. (1970), who also used the FerrantiShirley viscometer, reported from their studies on chronic bronchitis that purulent sputum was less viscid than either mucoid or mucopurulent. In the same study, Feather and Russell (1970), studying samples of sputum of various macroscopic types from children with cystic fibrosis, found that purulent sputum was usually more viscid than mucoid or mucopurulent if obtained from the same patient. In a study of sputum from patients with chronic bronchitis, again grouping all sputum of a given macroscopic type, the same trend for the individual patient was reported by Adler et al. 
(1972)-that the group of purulent sputa was not significantly more viscous.

Such differences in results may be explained partly by the rate of shear used for measurement, in the subjective assessment of macroscopic types, and in differences in the conditions of collection and storage of sputum. This last might alter viscosity if mucolysis had occurred before testing. It has been shown that it is mostly the presence of salivary enzymes (Leach, 1963), as well as of endogenous bronchial proteases (Bürgi, 1964; Lieberman et al., 1965) that contribute to the breakdown of bronchial secretions. It seems that if purulent sputum is tested soon after production it tends to be more viscid than is mucoid sputum.

Deoxyribonucleic acid may be present in sputum in solution, in cells, or as fibres. Presumably the fibres have formed from the DNA released by dissolution of polymorphonuclear leucocytes and bacteria as well as from cell debris of the respiratory epithelium. Bürgi (1964) used a simple fluorescent method that made it possible, by light microscopy, to assess the number of fibres present. He was able to assess in a semiquantitative way the number of fibres present and to follow the effect of antibiotics. Puchelle et al. (1973) found no significant correlation in sputum samples from a single patient between apparent viscosity measured at $0.3 \mathrm{~s}^{-1}$ and total DNA content, although when mucoid and mucopurulent samples were compared the mucopurulent samples had shown a significantly higher concentration of DNA and also a higher viscosity. In a study on cystic fibrosis (Rosenbluth and Chernick, 1974), there was likewise no relation between viscosity and DNA content.

Since a solution of DNA is viscous and has been shown to form a gel when a concentration of $0.1 \%$ is reached (Conway and Butler, 1954), it is perhaps surprising that no clearer correlation has emerged between the levels of viscosity and the content of DNA. In the present study, the total
DNA estimated and the concentration of DNA $\stackrel{\overrightarrow{\vec{N}}}{\stackrel{\vec{*}}{+}}$ fibres and cells have been assessed in a series of $\bar{C}$ sputum samples: these results are correlated with $\frac{\bar{F}}{\overline{0}}$ the type of sputum as assessed macroscopically, $\frac{\bar{N}}{\sigma}$ with the apparent viscosity of the sputum sample, $₫$ and with the total macromolecular dry weight $\&$ yield. The in vitro effect of adding DNA to $\vec{\circ}$ samples of sputum has also been investigated.

\section{Material}

One hundred sputum samples from patients suffer- $\underset{\omega}{\dot{\omega}}$ ing from chronic bronchitis (CB), cystic fibrosis iv (CF), bronchiectasis (B), and asthma (A) were N studied (Table 1).

The diagnosis was based on the Medical Re- 을 search Council definitions for chronic bronchitis and asthma, evidence of radiographic changes for $\frac{7}{0}$ bronchiectasis, and a positive sweat test for cystic fibrosis.

Sputum specimens were collected in sterile $\stackrel{D}{0}$ polythene containers over a period not exceeding three hours, usually in the morning but sometimes later during periods of physiotherapy. The sputum was classified according to its macroscopic appearance as either mucoid (M)-no evidence of pus; $\mathbb{D}$

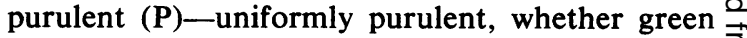
or yellow; or mucopurulent (MP)-mixed. The $\frac{9}{3}$ mucopurulent can be further divided into three grades-MMP, MP, and MPP-according to the amount of pus present. These grades correspond to the classification proposed by Miller and Jones (1963) based on a total cell count.

\section{Methods}

Within three hours of collection, rheological measurements were carried out on the fresh 0 sputum on a Ferranti-Shirley cone and plate viscometer fitted with a $200 \mathrm{gcm}$ torque spring. Two cones were used-a $7 \mathrm{~cm}$ diameter cone for the less viscous and a $4 \mathrm{~cm}$ cone for the more os viscous specimens. The shear rate developed be- $N$

Table 1 Details of patients studied

\begin{tabular}{|c|c|c|c|c|c|}
\hline & $\begin{array}{l}\text { Chronic bronchitis } \\
(C B)\end{array}$ & $\begin{array}{l}\text { Cystic fibrosis } \\
(C F)\end{array}$ & $\begin{array}{l}\text { Bronchiectasis } \\
(B)\end{array}$ & $\begin{array}{l}\text { Asthma } \\
(A)\end{array}$ & Total \\
\hline $\begin{array}{l}\text { No. of patients } \\
\text { Age: Range } \\
\quad \text { Median } \\
\text { Male } \\
\text { Female } \\
\text { No. of specimens } \\
\quad \text { Mucoid (M) } \\
\quad \text { Mucopurulent (MP) } \\
\text { Purulent (P) }\end{array}$ & $\begin{array}{l}35 \\
46-87 \\
64 \\
28 \\
7 \\
40 \\
19 \\
12 \\
9\end{array}$ & $\begin{array}{l}22 \\
9-33 \\
17 \\
10 \\
12 \\
29 \\
7 \\
7 \\
15\end{array}$ & $\begin{array}{l}13 \\
30-75 \\
64 \\
8 \\
5 \\
17 \\
1 \\
6 \\
10\end{array}$ & $\begin{array}{l}13 \\
22-70 \\
42 \\
8 \\
5 \\
14 \\
5 \\
5 \\
4\end{array}$ & $\begin{array}{l}83 \\
9-87 \\
54 \\
54 \\
29 \\
100 \\
32 \\
30 \\
38\end{array}$ \\
\hline
\end{tabular}


tween the cone and plate is a function of the rotational speed of the cone, and the shear stress exerted in the fluid tested is measured through the same cone by means of a torsion spring. A range of shear rates can be applied using uniform acceleration and deceleration of the cone over a 120 seconds sweep time for rotational speed ranging from 0-10 and 1-100 rpm.

The apparent viscosity is calculated from the ratio

$$
\begin{gathered}
\text { shear stress } / \text { shear rate }=\frac{\text { torque }}{\mathrm{rpm}} \mathrm{k} \\
\mathrm{k}=\frac{\text { constant torque }}{\text { constant spring }}
\end{gathered}
$$

The sputum specimen left after testing was stored at $-20^{\circ} \mathrm{C}$ for later chemical estimation. When required, the sample was thawed, boiled for 10 minutes, and dialysed against distilled water for 72 hours at $4^{\circ} \mathrm{C}$. The sample was then freezedried, reconstituted in distilled water, treated by ultrasound, pronase-treated, and diluted to the desired concentration for biochemical estimation. Final adjustment gave a concentration of 0.2 to $0.4 \mathrm{mg} / \mathrm{ml}$. A $1-\mathrm{ml}$ aliquot was used for DNA estimation according to the method of Burton (1956), modified by Croft and Lubran (1965) for sialic acid interference. The colorimetric reaction was developed at $30^{\circ} \mathrm{C}$ for 20 hours and the colorimetric absorption was read at $600 \mathrm{~nm}$ and then at $550 \mathrm{~nm}$ to eliminate sialic acid interference. The diphenylamine reagent was prepared by dissolving $2 \mathrm{~g}$ of diphenylamine in $10 \mathrm{ml}$ of glacial acetic acid, adding $1.5 \mathrm{ml}$ of concentrated $\mathrm{H}_{2} \mathrm{SO}_{4}$. Standards were prepared from a stock solution of calf thymus DNA at $1.4 \mathrm{mg} / \mathrm{ml}$ in $0.005 \mathrm{M} \mathrm{NaOH}$.

Thirty-five specimens were selected for quantitation of DNA fibres. The histological identification of DNA was based on the Feulgen reaction for DNA (Feulgen and Rossenbeck, 1967). The reaction is based upon the liberation of active aldehyde groups after the purine deoxyribose bond has been broken by acid hydrolysis. The free groups recolour Schiff's reagent, giving a purple colour to the nuclear chromatin. After fixation of the sputum smears within $\mathbf{3 0}$ minutes of collection in Schaudin's fixation, the slide was dipped in warm $\mathrm{N} \mathrm{HCl}\left(60^{\circ} \mathrm{C}\right)$ for hydrolysis, followed by staining in Schiff for $\mathbf{3 0}$ minutes. Counterstaining for 1 minute in $1 \%$ light green followed three rinses in sulphite. After dehydration and clearing in xylene, the slides were mounted on synthetic resin medium.
Slides were then examined under light microscopy at $\times 40$ magnification, and semiquantitative estimation of the number of cells and fibres was carried out separately according to the following classification:

$$
\begin{array}{ll}
- & \text { no evidence of fibres or cells } \\
+ & \begin{array}{l}
\text { few fibres or cells } \\
\text { scattered network of fibres or low cell } \\
\text { density } \\
\text { dense network of fibres or high cell } \\
\text { density }
\end{array}
\end{array}
$$

IN VITRO ADDITION OF DNA

In 2 aliquots of each of three specimens, DNA in its polymerised form was dissolved to give a final concentration of either $1 \mathrm{mg} / \mathrm{ml}$ or $5 \mathrm{mg} / \mathrm{ml}$. Dissolution took place at $4^{\circ} \mathrm{C}$ for an hour, the flask being shaken occasionally.

To $2 \mathrm{ml}$ from each of five other sputum specimens was added $1 \mathrm{ml}$ of a solution of DNA of $5 \mathrm{mg} / \mathrm{ml}$ in a phosphate buffer at pH 7.4, the final concentration being $1.66 \mathrm{mg} / \mathrm{ml}$. A minimum of two viscosity measurements were made at each DNA concentration and on control specimens. The results were recorded as the percentage increase in the level of apparent viscosity at $1350 \mathrm{~s}^{-1}$ as compared with the control specimen.

Student's $t$ test was used to compare the various groups.

\section{Results}

The two intermediate macroscopic types, MMP and MPP, were analysed to find out whether they could be included in either of the two main groups, $M$ and P. By Student's $t$ test it was found that there was no significant difference in the mean values of DNA between M and MMP in chronic bronchitis, and MPP and $P$ in bronchiectasis and cystic fibrosis; MMP results were therefore grouped with M, and MPP with P in those cases.

Results from the asthma group were too few to be treated as a separate disease but were included in the results of macroscopic type differences. Only one mucoid bronchiectasis sample was available at the time of the study and hence no comparison was made between the $M$ and MP type in this disease.

\section{MACROSCOPIC TYPE DIFFERENCES}

Table 2 shows for each macroscopic type the levels of apparent viscosity, macromolecular dry weight yield of the sputum, and the levels of DNA.

The levels of significance for the differences between each macroscopic type are given in 
Table 2 DNA content of sputum from various macroscopic types

\begin{tabular}{lccll}
\hline Sputum & $\begin{array}{l}\text { DNA } \\
(\% \text { of } \\
\text { dry weight })\end{array}$ & $\begin{array}{l}\text { DNA } \\
(\mathrm{mg} / \mathrm{ml})\end{array}$ & $\begin{array}{l}\text { Dry weight } \\
(\mathrm{mg} / \mathrm{ml})\end{array}$ & $\begin{array}{l}\text { Viscosity } \\
(\text { poise })\end{array}$ \\
\hline M & $0.60^{*}$ & $0 \cdot 10$ & $17 \cdot 78$ & 0.64 \\
& $(0 \cdot 18)$ & $(0.03)$ & $(1.68)$ & $(0.08)$ \\
MP & 1.38 & 0.33 & $24 \cdot 31$ & 0.71 \\
& $(0.38)$ & $(0.07)$ & $(2 \cdot 25)$ & $(0.11)$ \\
P & 3.25 & $1 \cdot 16$ & 36.73 & 0.64 \\
& $(0.31)$ & $(0.13)$ & $(2.58)$ & $(0.06)$ \\
\hline
\end{tabular}

* Mean.

Standard error in parentheses.

Table 3 Comparison of DNA concentration in the various macroscopic types of sputum

\begin{tabular}{|c|c|c|c|c|}
\hline Sputum & $\begin{array}{l}\text { DNA } \\
(\% \text { of } \\
\text { dry weight })\end{array}$ & $\begin{array}{l}D N A \\
(m g / m l)\end{array}$ & $\begin{array}{l}\text { Dry weight } \\
(\mathrm{mg} / \mathrm{ml})\end{array}$ & $\begin{array}{l}\text { Viscosity } \\
\text { (poise) }\end{array}$ \\
\hline $\mathbf{M} / \mathbf{M P}$ & $\begin{array}{c}2.887^{*} \\
(<0.01)\end{array}$ & $\begin{array}{r}3.078 \\
(<0.01)\end{array}$ & $\begin{array}{r}2.471 \\
(<0.02)\end{array}$ & $\begin{array}{l}0.295 \\
\text { (ns) }\end{array}$ \\
\hline $\mathbf{M P} / \mathbf{P}$ & $\begin{array}{c}4.802 \\
(<0.001)\end{array}$ & $\begin{array}{r}5.626 \\
(<0.001)\end{array}$ & $\begin{array}{c}3.623 \\
(<0.001)\end{array}$ & $\begin{array}{c}-0.515 \\
\text { (ns) }\end{array}$ \\
\hline $\mathbf{M} / \mathbf{P}$ & $\begin{array}{r}7 \cdot 759 \\
(<0.001)\end{array}$ & $\begin{array}{c}7.802 \\
(<0.001)\end{array}$ & $\begin{array}{c}6.153 \\
(<0.001)\end{array}$ & $\begin{array}{l}0.001 \\
\text { (ns) }\end{array}$ \\
\hline
\end{tabular}

*Student's $t$ value.

Level of significance in parentheses.

Table 3: DNA and dry weight levels increased significantly with the degree of purulence but viscosity did not show any consistent change.

The correlation coefficients between dry weight, DNA, and viscosity are given in Table 4. In purulent sputum, DNA and dry weight and dry weight and viscosity both showed a significant correlation. In the $\mathbf{M}$ and MP types, only dry weight and viscosity showed a positive correlation.

\section{DIFFERENCES BETWEEN DISEASES}

Absolute levels of DNA, dry weight, and viscosity for each disease and for each macroscopic type are given in Table 5. Comparison between diseases for

Table 4 Linear correlation coefficients between $D W$ and DNA and viscosity for various macroscopic types of sputum

\begin{tabular}{llll}
\hline Sputum & Dry weight/viscosity & DNA/dry weight & DNA/viscosity \\
\hline M & 0.745 & 0.117 & 0.119 \\
& $(<0.001)$ & $(\mathrm{ns})$ & (ns) \\
MP & 0.677 & 0.295 & -0.103 \\
& $(<0.001)$ & $(\mathrm{ns})$ & (ns) \\
P & 0.481 & 0.417 & -0.027 \\
& $(0.01)$ & $(<0.01)$ & $(\mathrm{ns})$ \\
\hline
\end{tabular}

Table 5 Mean DNA, dry weight, and viscosity for each macroscopic type of sputum and disease

\begin{tabular}{|c|c|c|c|c|c|}
\hline Sputum & Disease & $\begin{array}{l}D N A \\
(\% D W)\end{array}$ & $\begin{array}{l}D N A \\
(m g / m l)\end{array}$ & $\begin{array}{l}\text { Dry weight } \\
(m g / m l)\end{array}$ & $\begin{array}{l}\text { Viscosity } \\
\text { (poise) }\end{array}$ \\
\hline \multirow[t]{3}{*}{$\mathbf{M}$} & CB & $\begin{array}{l}0.43 \\
(0 \cdot 13)\end{array}$ & $\begin{array}{l}0.08 \\
(0.02)\end{array}$ & $\begin{array}{l}20.91 \\
(0.47)\end{array}$ & $\begin{array}{l}0 \cdot 75 \\
(0 \cdot 11)\end{array}$ \\
\hline & CF & $\begin{array}{l}1 \cdot 10 \\
(0 \cdot 23)\end{array}$ & $\begin{array}{l}0 \cdot 13 \\
(0.04)\end{array}$ & $\begin{array}{l}11 \cdot 27 \\
(1 \cdot 59)\end{array}$ & $\begin{array}{l}0.29 \\
(0.04)\end{array}$ \\
\hline & CB & $\begin{array}{l}1 \cdot 51 \\
(0 \cdot 43)\end{array}$ & $\begin{array}{l}0.41 \\
(0 \cdot 13)\end{array}$ & $\begin{array}{l}29 \cdot 58 \\
(4 \cdot 24)\end{array}$ & $\begin{array}{l}0.92 \\
(0.18)\end{array}$ \\
\hline \multirow[t]{3}{*}{ MP } & $\mathbf{B}$ & $\begin{array}{l}1 \cdot 60 \\
(0.45)\end{array}$ & $\begin{array}{l}0 \cdot 32 \\
(0 \cdot 11)\end{array}$ & $\begin{array}{l}19 \cdot 23 \\
(4 \cdot 24)\end{array}$ & $\begin{array}{l}0.36 \\
(0 \cdot 13)\end{array}$ \\
\hline & $\mathrm{CF}$ & $\begin{array}{l}1 \cdot 90 \\
(0 \cdot 36)\end{array}$ & $\begin{array}{l}0.40 \\
(0 \cdot 13)\end{array}$ & $\begin{array}{l}20 \cdot 70 \\
(4 \cdot 25)\end{array}$ & $\begin{array}{l}0.46 \\
(0.09)\end{array}$ \\
\hline & CB & $\begin{array}{l}2 \cdot 72 \\
(0 \cdot 55)\end{array}$ & $\begin{array}{l}1.09 \\
(0.24)\end{array}$ & $\begin{array}{l}39 \cdot 77 \\
(4 \cdot 10)\end{array}$ & $\begin{array}{l}0.92 \\
(0 \cdot 12)\end{array}$ \\
\hline \multirow[t]{2}{*}{$\mathbf{P}$} & B & $\begin{array}{l}2 \cdot 87 \\
(0 \cdot 53)\end{array}$ & $\begin{array}{l}0.95 \\
(0 \cdot 20)\end{array}$ & $\begin{array}{l}34 \cdot 25 \\
(1 \cdot 98)\end{array}$ & $\begin{array}{l}0.48 \\
(0.01)\end{array}$ \\
\hline & CF & $\begin{array}{l}3.62 \\
(0.59)\end{array}$ & $\begin{array}{l}1 \cdot 39 \\
(0 \cdot 51)\end{array}$ & $\begin{array}{l}38.95 \\
(5 \cdot 84)\end{array}$ & $\begin{array}{l}0.52 \\
(0.08)\end{array}$ \\
\hline
\end{tabular}

Standard error in parentheses.

Table 6 Comparison between macroscopic type and disease ( $\mathrm{t}$ values)

\begin{tabular}{|c|c|c|c|c|c|}
\hline Disease & & $\begin{array}{l}D N A \\
(\% D W)\end{array}$ & $\begin{array}{l}\text { DNA } \\
(m g / m l)\end{array}$ & $\begin{array}{l}\text { Dry weight } \\
(\mathrm{mg} / \mathrm{ml})\end{array}$ & $\begin{array}{l}\text { Viscosity } \\
\text { (poise) }\end{array}$ \\
\hline \multirow[t]{3}{*}{ CB } & $\mathbf{M} / \mathbf{M P}$ & $\begin{array}{l}2.427 \\
(<0.05)\end{array}$ & $\begin{array}{l}3.088 \\
(<0.01)\end{array}$ & $\begin{array}{l}1 \cdot 558 \\
\text { (ns) }\end{array}$ & $\begin{array}{l}0 \cdot 807 \\
\text { (ns) }\end{array}$ \\
\hline & $\mathbf{M P} / \mathbf{P}$ & $\begin{array}{l}2.136 \\
(<0.05)\end{array}$ & $\begin{array}{l}2 \cdot 897 \\
(<0.01)\end{array}$ & $\begin{array}{l}1 \cdot 730 \\
\text { (ns) }\end{array}$ & $\begin{array}{l}0.002 \\
\text { (ns) }\end{array}$ \\
\hline & $\mathbf{M} / \mathbf{P}$ & $\begin{array}{l}4.083 \\
(<0.001)\end{array}$ & $\begin{array}{l}4 \cdot 167 \\
(<0 \cdot 001)\end{array}$ & $\begin{array}{l}4 \cdot 090 \\
(<0.001)\end{array}$ & $\begin{array}{l}1 \cdot 060 \\
\text { (ns) }\end{array}$ \\
\hline \multirow[t]{2}{*}{ B } & $\mathbf{M P} / \mathbf{P}$ & $\begin{array}{l}1 \cdot 823 \\
\text { (ns) }\end{array}$ & $\begin{array}{l}2 \cdot 860 \\
(<0.02)\end{array}$ & $\begin{array}{l}2.774 \\
(<0.02)\end{array}$ & $\begin{array}{l}0.753 \\
\text { (ns) }\end{array}$ \\
\hline & $\mathbf{M} / \mathbf{M P}$ & $\begin{array}{l}1 \cdot 866 \\
\text { (ns) }\end{array}$ & $\begin{array}{l}2 \cdot 052 \\
\text { (ns) }\end{array}$ & $\begin{array}{l}2 \cdot 075 \\
\text { (ns) }\end{array}$ & $\begin{array}{l}1 \cdot 485 \\
\text { (ns) }\end{array}$ \\
\hline \multirow[t]{2}{*}{ CF } & $\mathbf{M P} / \mathbf{P}$ & $\begin{array}{l}2.490 \\
(<0.05)\end{array}$ & $\begin{array}{l}3.515 \\
(<0.001)\end{array}$ & $\begin{array}{l}2.526 \\
(<0.05)\end{array}$ & $\begin{array}{l}0.414 \\
\text { (ns) }\end{array}$ \\
\hline & $\mathbf{M} / \mathbf{P}$ & $\begin{array}{l}4.002 \\
(<0.001)\end{array}$ & $\begin{array}{l}4.952 \\
(<0.001)\end{array}$ & $\begin{array}{l}4.573 \\
(<0.001)\end{array}$ & $\begin{array}{l}1.448 \\
\text { (ns) }\end{array}$ \\
\hline
\end{tabular}

the same macroscopic type and between macroscopic types for each disease are given in Tables 6 o and 7.

For each disease, DNA, dry weight, and visosity levels showed an increase with the degree of $\omega$ purulence but the difference reached significance on all diseases only for DNA and dry weight $\varrho$ between $\mathbf{M}$ and $\mathbf{P}$.

Taking the same macroscopic type, no difference in DNA levels was found between diseases. In chronic bronchitis, dry weight tended to be higher than in cystic fibrosis and bronchiectasis sputum, and the differences reached significant levels for mucoid sputum.

For each macroscopic type, the apparent viscosity of $C B$ sputum was significantly higher than 
Table 7 Comparison between macroscopic type and disease ( $\mathrm{t}$ values)

\begin{tabular}{|c|c|c|c|c|c|}
\hline Disease & & $\begin{array}{l}D N A \\
(\% D W)\end{array}$ & $\begin{array}{l}\text { DNA } \\
(\boldsymbol{m g} / \boldsymbol{m} l)\end{array}$ & $\begin{array}{l}\text { Dry weight } \\
(m g / m l)\end{array}$ & $\begin{array}{l}\text { Viscosity } \\
\text { (poise) }\end{array}$ \\
\hline \multirow[t]{2}{*}{$\mathbf{M}$} & $\mathrm{CB} / \mathrm{CF}$ & $\begin{array}{l}2.544 \\
(<0.02)\end{array}$ & $\begin{array}{l}1 \cdot 129 \\
\text { (ns) }\end{array}$ & $\begin{array}{l}3.640 \\
(<0.002)\end{array}$ & $\begin{array}{l}4.055 \\
(<0.001)\end{array}$ \\
\hline & $\mathrm{CB} / \mathrm{CF}$ & $\begin{array}{l}0.689 \\
\text { (ns) }\end{array}$ & $\begin{array}{l}0.063 \\
\text { (ns) }\end{array}$ & $\begin{array}{l}1.479 \\
\text { (ns) }\end{array}$ & $\begin{array}{l}2.232 \\
(<0.05)\end{array}$ \\
\hline \multirow[t]{3}{*}{ MP } & $\mathrm{CB} / \mathrm{B}$ & $\begin{array}{l}0.039 \\
\text { (ns) }\end{array}$ & $\begin{array}{l}0.555 \\
\text { (ns) }\end{array}$ & $\begin{array}{l}1.923 \\
\text { (ns) }\end{array}$ & $\begin{array}{l}2.565 \\
(<0.05)\end{array}$ \\
\hline & CF/B & $\begin{array}{l}0.509 \\
\text { (ns) }\end{array}$ & $\begin{array}{l}0.522 \\
\text { (ns) }\end{array}$ & $\begin{array}{l}0 \cdot 244 \\
\text { (ns) }\end{array}$ & $\begin{array}{l}0.688 \\
\text { (ns) }\end{array}$ \\
\hline & $\mathrm{CB} / \mathrm{CF}$ & $\begin{array}{l}1 \cdot 120 \\
\text { (ns) }\end{array}$ & $\begin{array}{l}0.525 \\
\text { (ns) }\end{array}$ & $\begin{array}{l}0.116 \\
\text { (ns) }\end{array}$ & $\begin{array}{l}2.748 \\
(<0.02)\end{array}$ \\
\hline \multirow[t]{2}{*}{$\mathbf{P}$} & $\mathrm{CB} / \mathrm{B}$ & $\begin{array}{c}-0 \cdot 20 \\
(\mathrm{~ns})\end{array}$ & $\begin{array}{l}0.443 \\
\text { (ns) }\end{array}$ & $\begin{array}{l}1 \cdot 213 \\
(\mathrm{~ns})\end{array}$ & $\begin{array}{l}2.878 \\
(<0.02)\end{array}$ \\
\hline & $\mathrm{CF} / \mathrm{B}$ & $\begin{array}{l}0.939 \\
\text { (ns) }\end{array}$ & $\begin{array}{l}0.797 \\
\text { (ns) }\end{array}$ & $\begin{array}{l}0.761 \\
\text { (ns) }\end{array}$ & $\begin{array}{c}-0.379 \\
\text { (ns) }\end{array}$ \\
\hline
\end{tabular}

Table 8 Linear correlation coefficients between dry weight, DNA, and viscosity for various macroscopic types of sputum and disease

\begin{tabular}{llll}
\hline Sputum & Disease & Dry weight/viscosity & DNA/viscosity \\
\hline M & CB & 0.703 & -0.095 \\
& & $(<0.001)$ & (ns) \\
& CF & 0.124 & 0.688 \\
& (ns) & 0.738 & (ns) \\
& CB & $(<0.01)$ & -0.220 \\
& B & 0.855 & (ns) \\
MP & & $(<0.05)$ & 0.070 \\
& CF & 0.262 & (ns) \\
& & $(\mathrm{ns})$ & 0.679 \\
& CB & 0.875 & $(\mathrm{~ns})$ \\
& & $(<0.001)$ & 0.165 \\
& B & 0.217 & $(\mathrm{~ns})$ \\
P & (ns) & -0.312 \\
& CF & 0.754 & $(\mathrm{~ns})$ \\
& & $(<0.001)$ & 0.246 \\
& & & (ns) \\
\hline
\end{tabular}

that of CF sputum and, in the MP and $P$ type, CB sputum was more viscous than bronchiectatic. In other words, for the same macroscopic type it looks as if the differences in viscosity between CB and CF are greater than the differences between macroscopic types from the same disease. Correlation coefficients between DNA and viscosity, and dry weight and viscosity, are given in Table 8.

A significant correlation is seen between dry weight and viscosity for all three macroscopic types of CB sputum, for mucopurulent bronchiectasis sputum, and for purulent CF sputum. There is no significant correlation between DNA and viscosity for any group.
PUS CELLS, DNA FIBRES AND VISCOSITY

In 20 out of the 35 specimens selected for this study, DNA fibres were present. Pus cells might be seen without fibres but fibres did not occur without cells. Although the increase in the number of fibres and cells was directly linked to the total DNA content (Figure) viscosity levels did not seem to follow the same trend. Accordingly, no significant correlation was found in those specimens between the concentration of DNA fibres and viscosity. The same results were found when taking the other 15 specimens where there was no evidence of fibres.

The average levels of viscosity in the specimens containing fibres were similar to those without. The total DNA content was not significantly different.

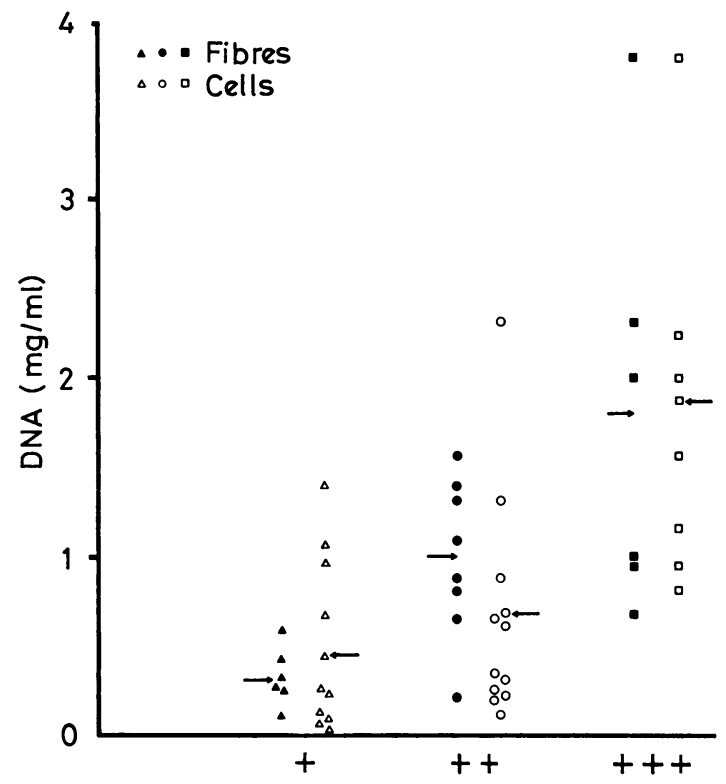

Fibre and cell densities

Figure Deoxyribonucleic acid (DNA) content of sputum smears related to cell and fibre content.

IN VITRO ADDITION OF DNA

In the first experiment, when the DNA was added in its freeze-dried form, the percentage increase in viscosity in three specimens studied ranged from 40 to $130 \%$ for the $4 \mathrm{mg} / \mathrm{ml}$ concentration but was insignificant and below $26 \%$ for the $1 \mathrm{mg}$ / $\mathrm{ml}$ (Table 9).

When DNA was added already dissolved in the phosphate buffer, the percentage increase ranged between 20 and $108 \%$ of the original viscosity 
Table 9 In vitro effect of addition of DNA

\begin{tabular}{|c|c|c|c|c|c|c|}
\hline Case & Diagnosis & $\begin{array}{l}\text { Macroscopic } \\
\text { type }\end{array}$ & $\begin{array}{l}\% \text { Increase in } \\
\text { viscosity } \\
(1 \mathrm{mg} / \mathrm{ml})\end{array}$ & $\begin{array}{l}\text { Student's } \\
\mathrm{t} \text { test } \\
(1 \mathrm{mg} / \mathrm{ml})\end{array}$ & $\begin{array}{l}\% \text { Increase in } \\
\text { viscosity } \\
(5 \mathrm{mg} / \mathrm{ml})\end{array}$ & $\begin{array}{l}\text { Student's } \\
\text { t test } \\
(5 \mathrm{mg} / \mathrm{ml})\end{array}$ \\
\hline \multicolumn{7}{|c|}{ In polymerised form } \\
\hline 1 & CB & $\mathbf{M}$ & NA & NA & $72 \cdot 32$ & $\begin{array}{l}1 \cdot 48 \\
\text { (ns)* }\end{array}$ \\
\hline 2 & CB & $\mathbf{P}$ & $17 \cdot 42$ & $\begin{array}{l}1.09 \\
(\mathrm{~ns})\end{array}$ & $42 \cdot 94$ & $\begin{array}{c}3.38 \\
(<0.05)\end{array}$ \\
\hline 3 & $\mathrm{CF}$ & $\mathbf{P}$ & $25 \cdot 67$ & $\begin{array}{l}0.97 \\
\text { (ns) }\end{array}$ & $129 \cdot 10$ & $\begin{array}{c}3.90 \\
(<0.02)\end{array}$ \\
\hline \multicolumn{7}{|c|}{ Dissolved in phosphate buffer at pH 7.4} \\
\hline 4 & B & $\mathbf{P}$ & $54 \cdot 40$ & $\begin{array}{l}2 \cdot 18 \\
\text { (ns) }\end{array}$ & & \\
\hline 5 & CF & $\mathbf{P}$ & & NA & & \\
\hline 6 & $\mathrm{CF}$ & $\mathbf{M}$ & $53 \cdot 90$ & $\begin{array}{c}6.13 \\
(<0.01)\end{array}$ & & \\
\hline 7 & CB & MMP & $108 \cdot 70$ & $\begin{array}{l}1 \cdot 12 \\
(\mathrm{~ns})\end{array}$ & & \\
\hline 8 & A & MMP & $20 \cdot 35$ & $\begin{array}{l}0 \cdot 57 \\
\text { (ns) }\end{array}$ & & \\
\hline
\end{tabular}

in four out of five specimens studied, there being no change in the fifth specimen (Table 9). Although the results show a wide scatter, it seems that the percentage increase in viscosity is inversely proportional to the original level of apparent viscosity.

\section{Discussion}

Sputum exhibits the rheological properties of a viscoelastic semisolid material (Davis and Dippy, 1969; Davis, 1973; Litt, et al., 1974; Litt et al., 1976); in the present study we have dealt only with its viscosity. The Ferranti-Shirley viscometer has been used by several authors to measure the apparent viscosity of sputum (Feather and Russell, 1970; Palmer et al., 1970; Davis, 1973). Although in the act of shearing there is disruption of the material the measurement at a given shear rate is made before this occurs; and it has been shown that a given shear rate does not produce the disruption achieved by a higher one. Absolute levels of viscosity are lower at high than low shear rates and less discriminate, but there is a correlationthat is, the more viscous secretion at low shear rates is still more viscous at higher shear rates (Charman and Reid, 1972).

Although purified DNA solutions are known to have high levels of viscosity and elasticity the DNA present in sputum seems to have little effect on either viscosity or elasticity. The lack of correlation between DNA content and apparent viscosity reported here does not seem to be due to the type of instrument used or the level of shear rate applied since Puchelle et al. (1973), using a Roto- visko viscometer at low shear rate $\left(0.3 \mathrm{~s}^{-1}\right)$, also found no correlation between DNA content and either apparent viscosity or elastic recovery.

Even in total purulent sputum DNA does not contribute more than $5 \%$ to the total dry weight $\frac{D}{\mathbb{D}}$ of the macromolecular solids, and this could $\varrho$ explain the small increase in viscosity.

Purulence also induces an increase in other biochemical constituents than DNA. In a group of chronic bronchitics, Puchelle et al. (1973) reported an increase in secretory $\operatorname{IgA}$ and sialomucins (expressed as $\mathrm{mg} / \mathrm{ml}$ ) in purulent as compared to mucoid sputum. In the same disease, LopezVidriero et al. (1973) found a marked increase 3 in fucose and $\mathrm{N}$-acetyl neuraminic acid (NANA). Fucose has already been described as a 'marker' substance for the bronchial glycoproteins (Keal, 1971). The ratio NANA/fucose was higher in purulent sputum showing a relatively greater con- $\frac{D}{0}$ tribution from the serum glycoprotein component to the final composition of sputum. In the light of $\widetilde{\sigma}$ those results, it can be suggested that although N the total dry weight of the bronchial fluid becomes N higher due both to the increased concentration of gland secretion and serum exudate, the dilution effect brought about by the serum when the sputum becomes purulent could explain why the viscosity does not show a greater change. Further support for this suggestion can be found in the work of Bürgi et al. (1965) and Molina et al. (1969), who showed that in both asthma and $\frac{\mathbb{D}}{\mathbb{Q}}$ chronic bronchitis sputum viscosity did not de- 응 crease when infection was controlled by antibiotics and sputum became mucoid. In some cases $\delta$ viscosity was found to be even higher. In the 
absence of infection, degradation of the mucopolysaccharides (MPS) is less since the main sources of proteolytic enzymes, bacteria, and polymorphonuclear leucocytes disappear. At this clinical stage the viscosity seems to depend on the presence of more intact MPS even if the DNA levels fall drastically after the antibiotic treatment. Lieberman and Kurnick (1963), working with sputum homogenates, stressed the fact that the more purulent the sputum the higher the enzymic activity because of the polymorphonuclears present. This activity was very high in cystic fibrosis, slightly lower in bronchiectasis, and much lower in the other pulmonary diseases studied. In a further study, Lieberman (1967) proved that separation of the enzyme proteins from the DNA was necessary for the proteases to exert their activity, showing DNA to behave as an inhibitor at around $\mathrm{pH}$. Those findings were related to the discovery that protease activity could be enhanced after DNase treatment and was higher at pH 7.5 than at a lower pH (Lieberman, 1967). Guerrin et al. (1969) found that in normal subjects the $\mathrm{pH}$ measured in situ at different levels of the bronchial tree ranged between 7 and $7 \cdot 5$; inducing hypoxia associated with hypercapnia (rebreathing) in rabbits, a slight acidosis and a raised PcO2 occurred followed by a slight fall in bronchial $\mathrm{pH}$ from 6.51 to $6 \cdot 17$.

In our studies sputum $\mathrm{pH}$ has always been above 7 in bronchial diseases and also in sputum produced after inhalation of prostagandin F2 alpha in normal subjects (Lopez-Vidriero et al., 1977). Those results are well in agreement with those of Adler et al. (1972), who found that sputum $\mathrm{pH}$ in the purulent type $(7 \cdot 83)$ was slightly higher than in the mucoid type (7.59).

It seems therefore that the conditions described by Lieberman (1967) in vitro do not recreate exactly the in vivo conditions where $\mathrm{pH}$ seems to be mostly alkaline and protease activity is encouraged. Thus, in our study, although purulent sputa from cystic fibrosis and bronchiectasis have a high dry weight and total DNA content, they have nevertheless the lowest viscosity level; the histological preparations show that smears of cystic fibrosis and bronchiectasis sputum have the highest density of bundles of fibres but, since the highest levels of protease activity are found in those diseases (Lieberman, 1967), it could well be that the breakdown of MPS is more important than the formation of DNA fibres and hence the viscosity would tend to be lower. In mucoid sputum, levels of viscosity are significantly lower in cystic fibrosis than in chronic bronchitis. In cystic fibrosis, levels of mannose (marker sugar for the serum transudate) and NANA/fucose in sputum have been shown to be high (Lopez-Vidriero, 1976). It may be that an increase in exudate component from the inflammatory reaction is diluting the glycoprotein and DNA content. In chronic bronchitis, although the average dry weight increase from the MP to $P$ type is more than 10 $\mathrm{mg} / \mathrm{ml}$, viscosity levels are similar in the two types. Here again, a higher degree of purulence could be responsible for a rapid and important mucolysis and so lower the sputum viscosity.

The results of microscopic examination of the sputum smears related to those for viscosity support these findings. Even when DNA is present in its fibre form, poor correlation emerged between DNA and viscosity, stressing the important effect of mucolysis and dilution of purulent sputum by serum. From a previous report (Charman and Reid, 1972) it seems that purulent specimens show a wider variance in viscosity than the mucoid type. This can be explained by the different degree of MPS breakdown in different specimens even if the experimental conditions are strictly controlled. Variations of this type could occur even from differences in the habit of expectoration; retention of secretion within the bronchus might lead to significant mucolysis even before expectoration. It seems that the presence of DNA in sputum contributes little to its viscosity even though the in vitro effect of DNA suggests the reverse.

We thank the clinicians and physiotherapists at the Brompton Hospital who have made available material and information from their patients; also Dr. E. Keal and Dr. M. T. Lopez-Vidriero for consultations, and Mr. K. Stephens for the histological preparations. The work has been supported by grants from the Medical Research Council and Cystic Fibrosis Research Trust.

\section{References}

Adler, K., Wooten, O., Philippoff, W., Lerner, E., and Dulfano, J. M. (1972). Physical properties of sputum: 3. Rheological variability and intrinsic relationships. American Review of Respiratory Diseases, 106, 86-96.

Bruce, K. A., and Quinton, K. C. (1962). Effect of oran alpha-chymotrypsin on sputum viscosity. British Medical Journal, 1, 282-284.

Bürgi, H. (1964). Die Viskosität des purulenten und sterilen Sputums bei chronischer Asthmabronchitis. Medicina Thoracicalis, 21, 156-167.

Bürgi, H., Regli, J., and Medici, T. (1965). New findings from studies of sputum fibre systems in asthma and chronic bronchitis. Médecine et Hygiène, 23, 1169-1171. 
Burton, K. (1956). A study of the conditions and mechanism of the diphenylamine reaction for the colorimetric estimation of deoxyribonucleic acid. Biochemical Journal, 62, 315-323.

Charman, J., and Reid, L. (1972). Sputum viscosity in chronic bronchitis, bronchiectasis, asthma and cystic fibrosis. Biorheology, 9, 185-199.

Conway, B. E., and Butler, J. A. (1954). Effect of salts on the interaction of nucleic acid particles. Journal of Polymer Science, 12, 199-208.

Croft, D. N., and Lubran, M. (1965). The estimation of DNA in the presence of sialic acid: application to analysis of human gastric washing. Biochemical Journal, 95, 612-620.

Davis, S. S. (1973). Techniques for the measurement of rheological properties of sputum. Bulletin de Physiopathologie Respiratoire, 9, 47-90.

Davis, S. S., and Dippy, J. E. (1969). The rheological properties of sputum. Biorheology, 6, 11-22.

Feather, E. A., and Russell, G. (1970). Sputum viscosity in cystic fibrosis of the pancreas and other pulmonary diseases. British Journal of Diseases of the Chest, 64, 192-200.

Feulgen, R., and Rossenbeck, H. (1967). Quoted in Carleton's Histological Technique, edited by R. A. B. Drury and E. A. Wallington, 4th edition, p. 158. Oxford University Press, London.

Guerrin, F., Voisin, C., Maquet, V., Robin, H., Wattel, F., and Boulanger, P. (1969). Resultats de la pH métrie bronchique 'in situ'. In Hypersécrétion Bronchique, Colloque International de Pathologie Respiratoire, edited by Poinsot, R. Clichy, p. 249. Lille, 27-29 Sept. 1968.

Keal, E. E. (1971). Biochemistry and rheology of sputum in asthma. Postgraduate Medical Journal, 47, 171-177.

Leach, S. A. (1963). Release and breakdown of sialic acid from human salivary mucin and its role in the formation of dental plaque. Nature, 199, 486-487.

Lieberman, J. (1967). Inhibition of protease activity in purulent sputum by DNA. Journal of Laboratory and Clinical Medicine, 70, 595-605.

Lieberman, J., and Kurnick, N. (1963). Proteolytic enzyme activity and the role of deoxyribonucleic acid in cystic fibrosis sputum. Pediatrics, 31, 10281032.

Lieberman, J., Trimmer, B. M., and Kurnick, N. B. (1965). Substrate specificity of protease activities in purulent sputum. Laboratory Investigation, 14, 249 257.
Litt, M., Khan, M. A., Chakrin, L. W., Wardell, J. R. and Christian, P. (1974). The viscoelasticity of fractionated canine tracheal mucus. Biorheology, 11, $\frac{\partial}{\mathrm{c}}$ 111-117.

Litt, M., Khan, M. A., and Wolf, D. P. (1976). Mucus $\stackrel{\odot}{\varrho}$ rheology: relation to structure and function. Biorheology, 13, 37-48.

Lopez-Vidriero, M. T. (1976). Neuraminic acid, fucose. and sulphate of sputum: in disease and during treat- $\overrightarrow{-}$ ment. PhD thesis, University of London.

Lopez-Vidriero, M. T., Charman, J., Keal, E., de Silva, D. J., and Reid, L. (1973). Sputum viscosity: $\times$ correlation with chemical and clinical features in $\omega_{\mathcal{U}}^{\omega}$ chronic bronchitis. Thorax, 28, 401-408.

Lopez-Vidriero, M. T., Das, I., Smith, A. P., Picot, i R., and Reid, L. (1977). Bronchial secretion frome normal human airways after inhalation of pro-응 staglandin F2a, acetylcholine, histamine, and citric acid. Thorax, 734-739.

Miller, D. L., and Jones, R. (1963). A study of tech-을 niques for the examination of sputum in a field survey of chronic bronchitis. American Review of 9 Respiratory Diseases, 88, 473-483.

Molina, C., Aiache, J. M., Delage, J., and Pradelle, M. (1969). Viscométrie des expectorations. Journal@ Français de Médecine et Chirologie Thoracique, 23, 734-758.

Palmer, K. N. V., Ballantyne, D., Diament, M. L., پ and Hamilton, W. F. D. (1970). The rheology of bronchitic sputum. British Journal of Diseases of $\overrightarrow{\vec{O}}$ the Chest, 64, 185-191.

Puchelle, E., Zham, J. M., and Havez, R. (1973).J Données biochimiques et rhéologiques dans l'expectoration. 3. Relation des proteines et mucines bronchiques avec les propriétés rhéologiques. Bulle $\overrightarrow{\widehat{\sigma}}$ tin de Physiopathologie Respiratoire, 9, 237-257.

Rosenbluth, M., and Chernick, V. (1974). Influence of mist tent therapy on sputum viscosity and water? content in cystic fibrosis. Archives of Disease in Childhood, 49, 606-610.

Sturgess, J., Palfrey, A. J., and Reid, L. (1971) Rheological properties of sputum. Rheologica Acta옹 10, 36-43.

Requests for reprints to: Dr. Lynne Reid, Department of Pathology, Children's Hospital Medical Center Harvard Medical School, 300 Longworth Avenue, Boston, Massachusetts 02115, USA. 